\title{
Quality Comparison of Hawthorn Wines Fermented by Saccharomyces cerevisiae with and without Pulp Contact and Pectase Treatment
}

\author{
Wenye Zhang, ${ }^{1}$ Lei Chi, ${ }^{1}$ Yan $\mathrm{Wu}^{2}{ }^{2}$ Lei Zhang, ${ }^{1}$ and Chunping Xu${ }^{1}$ \\ ${ }^{1}$ College of Food and Biology Engineering, Zhengzhou University of Light Industry, Zhengzhou 450002, China \\ ${ }^{2}$ Technical Center of China Tobacco Guangxi Industrial Co. Ltd., Nanning 530001, China \\ Correspondence should be addressed to Chunping Xu; c.p.xu@zzuli.edu.cn
}

Received 13 May 2017; Revised 6 August 2017; Accepted 27 August 2017; Published 12 October 2017

Academic Editor: Ewa Schab-Balcerzak

Copyright (c) 2017 Wenye Zhang et al. This is an open access article distributed under the Creative Commons Attribution License, which permits unrestricted use, distribution, and reproduction in any medium, provided the original work is properly cited.

\begin{abstract}
This study evaluated the chemical and volatile composition of hawthorn wines fermented with Saccharomyces cerevisiae A3.12 with and without pulp contact and pectase treatment during fermentation. The results indicated that the addition of pectase was in favor of $\mathrm{pH}$ decrease and clarification. The pectase-treated wines had significantly higher concentrations of acetic acid, ethyl octanoate, and isoamyl acetate than the non-enzyme-treated wines. Furthermore, the nonextracted wines had significantly higher concentrations of isoamyl alcohol, phenylethyl alcohol, ethyl lactate, and isoamyl acetate than the extracted wines. The first principal component separated the wine from the nonextracted juice with pectase from other samples based on the higher concentrations of isoamyl acetate $(0.14 \mu \mathrm{g} / \mathrm{g})$, diethyl butanedioate $(0.07 \mu \mathrm{g} / \mathrm{g})$, 2-phenylethyl acetate $(0.23 \mu \mathrm{g} / \mathrm{g})$, and acetoin $(1.47 \mu \mathrm{g} / \mathrm{g})$. The wine from nonextracted pulpy juice with pectase was significantly more aromatic than the others and $26.2 \%$ of the consumers were found to be willing to purchase this product.
\end{abstract}

\section{Introduction}

Chinese hawthorn (Crataegus pinnatifida) is a member of family Rosaceae. It is an edible fruit used in traditional Chinese medicine to improve digestion and increase appetite [1]. Hawthorn is an important plant in traditional Chinese medicine and is recommended for the treatment of some diseases such as tumors and cardiovascular disease related to the production of radical species resulting from oxidative stress $[2,3]$.

Compared with hawthorn fruits, studies on hawthorn wine fermentation and volatiles in hawthorn wines are limited. Hawthorn wine can be produced by fermentation with Saccharomyces cerevisiae. He et al. investigated the chemical characteristics and antioxidant capacities of hawthorn wines by the fermentation of different yeast strains [4]. It was found that the wine compositions and antioxidant activities showed expected variations. In spite of the studies described above, it still needs strive to optimize the fermentation processing to improve the quality of hawthorn wine.
In order to improve fruit wine quality, many different enzymes were applied to solve the processing problems [5-7]. For example, Apolinar-Valiente et al. reported $\beta$ galactosidase was used to affect oligosaccharide composition of Monastrell red wines [8]. González-Neves et al. found that maceration enzymes affect the anthocyanin profile and the stability of the color of grape wines [9]. In our previous study, that pulp contact and protease were proved to be able to improve the intensity and complexity of jujube wine aroma due to the increase of the assimilable nitrogen [10]. Pectases have been used in wine production since the 1960s. The pectase can help break down the fruit material and extract flavors from the mash, and also the presence of pectin can improve the clarity in finished wine [11, 12]. In spite of the studies described above, the effects of pectase on the chemical and volatile profiles of hawthorn wines remain unclear. Thus, the aim of this study was to evaluate the chemical and volatile composition of the resultant hawthorn wines fermented by S. cerevisiae A3.12 with and without pulp contact. The effectiveness of pectase application in hawthorn wine flavor 
modification was investigated as well. The information gained would be useful for the processing in order to produce hawthorn wines with differential characteristics.

\section{Materials and Methods}

In this study, we followed the methods of Zhang et al. (2016) [10] with slight modification. The detailed procedure was as follows.

2.1. Yeast Strains and Culture Media. S. cerevisiae A3.12 commercial wine yeast (Angel Yeast Co., Ltd., China) was used in the hawthorn fermentation. 2.4 gram freeze-dried yeast powder was propagated in the $150 \mathrm{~mL}$ broth of fresh juice (adjusted to ${ }^{\circ}$ Brix of $4.0 \%$ described below) at $38^{\circ} \mathrm{C}$ for $1 \mathrm{~h}$ under static conditions and yeasts grew to $10^{7} \mathrm{CFU} / \mathrm{mL}$ for use immediately.

2.2. Pretreatment of Hawthorn Juice. The variety of hawthorn sample used in this study was Yubeihong, an improved breed cultivated in north part of Henan province, China. The dried hawthorn was purchased from a local wholesale centre in Xinzheng, Henan, China. The hawthorn (950 gram) was rinsed in $2850 \mathrm{~mL}$ distilled water $(1: 3 \mathrm{w} / \mathrm{v})$ overnight. Then the hawthorn was cooked at $90^{\circ} \mathrm{C}$ for $5 \mathrm{~h}$ and continually at $100^{\circ} \mathrm{C}$ for $1 \mathrm{~h}$. The cooked hawthorn was divided into two lots. The first lot was extracted manually by 4 layer cottongauze filter to remove the pulp ( ${ }^{\circ}$ Brix $\left.13.7 \%\right)$. The second lot was not extracted and ${ }^{\circ}$ Brix was detected as $14.3 \%$. The sugar concentrations of extracted and unextracted juice were 135.4 and $143.9 \mathrm{~g} / \mathrm{L}$, respectively. All experiments were performed at least in triplicate to collect enough samples.

2.3. Fermentation and Pectase Treatment. The hawthorn juice fermentation was carried out in 1000-mL sterile Erlenmeyer conical flasks (plugged with cotton wool and then wrapped with aluminium foil), and each flask contained $800 \mathrm{~mL}$ of extracted hawthorn juice or unextracted pulpy hawthorn juice. Before inoculation, the samples were divided into two portions. One portion was subjected to pectase treatment (Imperial Jade biotechnology Co., Ltd, China; Enzymatic activity $\geqq 3 \times 10^{5} \mu / \mathrm{g}$; enzyme dosage of $0.3 \mathrm{~g} / \mathrm{L}$ ) at $45^{\circ} \mathrm{C}$ for $1 \mathrm{~h}$ and the other portion was kept at $45^{\circ} \mathrm{C}$ for $1 \mathrm{~h}$ as control. All four different samples were inoculated with $1.25 \%(\mathrm{v} / \mathrm{v})$ of yeast broth culture. The fermentation was conducted at $22^{\circ} \mathrm{C}$ statically for 24 days. All pectase treatments and controls were carried out in triplicate. Samples collected at the end of the fermentation were centrifuged at $3,000 \mathrm{~g}$ for $15 \mathrm{~min}$, and the resulting supernatant was stored at $4^{\circ} \mathrm{C}$ for the other ten days before further analysis.

2.4. Measurement of $\mathrm{pH},{ }^{\circ}$ Brix, and Clarity. The total soluble solids ( ${ }^{\circ}$ Brix) and $\mathrm{pH}$ were measured at the indicated time points by using a refractometer (PAL-1, ATAGO, Japan) and a pH meter (Mettler-Toledo, Switzerland), respectively. The clarity of wine was recorded at $680 \mathrm{~nm}$ using a Leng Guang 722 spectrophotometer [13] and distilled water is used as a control. Samples were analyzed in triplicate for each wine.

2.5. Analysis of Total Sugars, Reducing Sugars, and Methanol. The contents of total sugar, reducing sugars, and methanol were quantified according to the National Standard of the People's Republic of China [14].

2.6. Extraction and Analysis of Volatile Compounds. Simultaneous distillation extraction was developed to extract and concentrate volatile compounds from hawthorn wine and performed with a Likens-Nickerson apparatus [15]. For distillation, $150 \mathrm{~mL}$ hawthorn wine mixed with 50 distilled water and $60 \mathrm{~mL}$ dichloromethane were placed in a roundbottom flask in a water-bath (around $50^{\circ} \mathrm{C}$ ) for $2 \mathrm{~h}$. When the extraction was performed, chilled water was circulated through the cold finger condenser. $1 \mathrm{~mL}$ phenylethyl acetate dichloromethane solution $(0.62 \mathrm{mg} / \mathrm{mL})$ was added in the extract as internal standard. The samples were concentrated to $1.0 \mathrm{~mL}$ for further GC-MS analysis.

GC-MS analysis of volatile aromatic compounds was carried out on an Agilent 5973 mass select detector (Agilent Corporation of America) directly coupled to a HP-5 gas chromatograph $(60 \mathrm{~m} \times 250 \mu \mathrm{m} \times 0.25 \mu \mathrm{m})$. The temperature of the GC-MS transfer line was $280^{\circ} \mathrm{C}$ in the electron impact (EI) mode $(70 \mathrm{eV})$, scanning from $\mathrm{m} / z$ 35 550 in one scan. The column oven was programmed from $50^{\circ} \mathrm{C}$ (after $2 \mathrm{~min}$ ) to $280^{\circ} \mathrm{C}$ at $4^{\circ} \mathrm{C} / \mathrm{min}$ and the final temperature was held for $15 \mathrm{~min}$. The voltage of the electronic multiplier tube (EMT) was $230 \mathrm{~V}$ above tuning.

The mass spectral identification of aromatic compounds was carried out by comparing to the Nist11.L (USA Agilent Corporation). Qualitative analysis (mass spectral data) was verified by comparing the retention indices and mass spectra of identified compounds. The relative quantity of each compound was determined using acetic acid phenyl ester dichloromethane as the internal standards, without considering recovery of aroma compounds and response factors [16]; all sorts of aroma components were analyzed quantitatively as follows:

$$
\text { Aroma components extraction }(\mathrm{mg} / \mathrm{g})=\frac{(\text { peak area of aroma components } \times \text { quality of internal standard })}{(\text { internal standard peak area } \times \text { quality of sample })} .
$$

2.7. Sensory Analysis. Four wine samples (140 mL per sample) were assessed by a panel of seven trained flavorists from our department [17]. The four wine samples were assessed in the following order: (i) wine from the extracted juice with pectase; (ii) wine from the extracted juice without pectase; (iii) wine from nonextracted pulpy juice with pectase; (iv) wine from nonextracted pulpy juice without pectase. A set of descriptive terms for nine attributes were rated on a five-point 
TABLE 1: Physicochemical properties and total reducing sugar concentration of extracted and nonextracted wine, with and without pectase treatment.

\begin{tabular}{|c|c|c|c|c|}
\hline & \multicolumn{2}{|c|}{ Extracted } & \multicolumn{2}{|c|}{ Nonextracted } \\
\hline & Pectase & Control & Pectase & Control \\
\hline $\mathrm{pH}$ & $2.82 \pm 0.01^{\mathrm{a}}$ & $2.89 \pm 0.02^{\mathrm{b}}$ & $2.79 \pm 0.02^{\mathrm{a}}$ & $2.90 \pm 0.03^{\mathrm{b}}$ \\
\hline Total soluble solids ( $\left.{ }^{\circ} \mathrm{Brix}\right)$ & $6.38 \pm 0.10^{\mathrm{a}}$ & $5.93 \pm 0.23^{\mathrm{b}}$ & $6.80 \pm 0.65^{\mathrm{a}}$ & $5.87 \pm 0.32^{\mathrm{ab}}$ \\
\hline Clarity (\%) & $91.17 \pm 3.78^{\mathrm{a}}$ & $79.91 \pm 1.66^{\mathrm{b}}$ & $91.89 \pm 0.67^{\mathrm{a}}$ & $85.84 \pm 1.22^{\mathrm{c}}$ \\
\hline Cell count $\left(10^{6} \mathrm{cfu} / \mathrm{mL}\right)$ & $9.30 \pm 0.71^{\mathrm{a}}$ & $11.5 \pm 1.65^{\mathrm{a}}$ & $69.40 \pm 10.56^{\mathrm{b}}$ & $35.00 \pm 18.38^{\mathrm{c}}$ \\
\hline Total sugars (g/L) & $8.22 \pm 0.68^{\mathrm{a}}$ & $7.40 \pm 1.48^{\mathrm{a}}$ & $8.64 \pm 0.87^{\mathrm{a}}$ & $7.85 \pm 0.78^{\mathrm{a}}$ \\
\hline Total reducing sugars $(\mathrm{g} / \mathrm{L})$ & $6.75 \pm 0.64^{\mathrm{a}}$ & $5.80 \pm 0.94^{\mathrm{a}}$ & $6.40 \pm 2.78^{\mathrm{a}}$ & $5.50 \pm 1.11^{\mathrm{a}}$ \\
\hline Ethanol (\% v/v) & $7.53 \pm 0.21^{\mathrm{a}}$ & $6.50 \pm 0.20^{\mathrm{b}}$ & $7.13 \pm 0.21^{\mathrm{a}}$ & $7.67 \pm 0.21^{\mathrm{a}}$ \\
\hline Total acid (g/L) & $10.68 \pm 0.25^{\mathrm{a}}$ & $9.83 \pm 0.16^{\mathrm{b}}$ & $12.28 \pm 1.87^{\mathrm{a}}$ & $10.24 \pm 0.15^{\mathrm{a}}$ \\
\hline Pectin $(g / L)$ & n.d. ${ }^{\mathrm{a}}$ & $2.67 \pm 0.14^{\mathrm{b}}$ & n.d. ${ }^{\mathrm{a}}$ & $1.99 \pm 0.05^{\mathrm{c}}$ \\
\hline Methanol (mg/L) & $349.68 \pm 10.32^{\mathrm{a}}$ & $65.70 \pm 6.86^{\mathrm{b}}$ & $362.36 \pm 14.41^{\mathrm{c}}$ & $117.30 \pm 6.34^{\mathrm{d}}$ \\
\hline
\end{tabular}

${ }_{\mathrm{a}, \mathrm{b}, \mathrm{c}, \mathrm{d}}$ Statistical analysis at $95 \%$ confidence level with same letters indicating no significant difference.

scale for the intensity perceived, where zero indicated that the descriptor was not perceived and twenty indicated a very high intensity.

2.8. Consumer Acceptability Test. The consumer acceptability tests were made by 150 students in our department and four wine samples (6 L per sample) were assessed. A set of descriptive terms, overall, taste and flavor acceptance, were rated on a nine-point scale for the intensity of liking, where zero indicated the least and nine indicated the best [18]. Besides, a questionnaire survey of puncher intention was presented as well.

2.9. Statistical Analysis. The statistical differences of the effect of yeast treatment on the volatiles of hawthorn wine fermented with and without pulp (or pectase treatment) were evaluated using analysis of variance (ANOVA) in SPSS (version 12.0). All tests of significance were conducted at a probability level of $P<0.05$. Means and standard deviations were obtained from triplicate fermentation samples. The volatile and aroma profiles for pectase-treated hawthorn wines and control were further analyzed using principal component analysis (PCA) to characterize the multidimensional data.

\section{Results and Discussion}

3.1. Physicochemical Properties of Hawthorn Wine with and without Extraction and Enzyme Treatment. As shown in Table 1, after fermentation, the $\mathrm{pH}$ value was slightly lower (Brix value and clarity were higher) for pectase-treated wines than that without enzyme treatment for both extracted and nonextracted wines. The results indicated that the addition of pectase was in favor of $\mathrm{pH}$ decrease and clarification, which was consistent with the results reported by Cheirsilp and Umsakul [19]. However, the cell number was much higher for nonextracted wine compared with extracted wine for both enzyme and nonenzyme treatments, which indicated that nonextracted wines might be better for cell growth due to more complicated nutrition. Four wines have similar characteristics in terms of total sugars change and total reducing sugars changes after fermentation. The total soluble solids were $5.87-6.80^{\circ} \mathrm{Brix}$, while the total sugars and total reducing sugars are $7.4-8.64 \mathrm{~g} / \mathrm{L}$ and $5.50-6.75 \mathrm{~g} / \mathrm{L}$, respectively (Table 1). The pectin was degraded completely by pectase treatment. The methanol content was higher for pectasetreated wine than nonenzyme-treated wines, which indicated that pectase treatment would lead to more methanol production [20]. According to Agricultural Industry Standard of the People's Republic of China [21], the methanol contents in all wine samples are strictly regulated at $<400 \mathrm{mg} / \mathrm{L}$.

3.2. Volatiles. Thirty-eight volatiles were identified and quantified in the hawthorn wines with thirty-four volatiles being present in all wines (Table 2). The results showed pulp contact with pectase could improve the complexity of wine aroma. The alcohols accounted for the highest amount in hawthorn wines. Isoamyl alcohol was most abundant, which made up $62.20 \%-63.53 \%$ of the total amount of the alcohols in four hawthorn wines. Isoamyl alcohol was likely derived from leucine via the Ehrlich pathway [22]. Phenylethyl alcohol was second most abundant, which was likely derived from phenylalanine via the Ehrlich pathway [23]. The nonextracted wines had significantly higher concentrations of isoamyl alcohol and phenylethyl alcohol than the extracted wines. There was statistically significant difference between the concentrations of alcohols after extraction, including 1-propanol, isobutyl alcohol, Isoamyl alcohol, 3-hexen-1-ol, 2,3-butanediol, alphaterpineol, phenylethyl alcohol, and 3-ethyl-1-butanol, which could be related to the higher availability of relative amino acids in pulpy juice [24].

The second most abundant volatile group in the hawthorn wines was the acid group (Table 2). The major organic acids in hawthorn wine were acetic acid and isobutyric acid, which represented above $59 \%$ of the total organic acids. The pectasetreated wines had significantly higher concentrations of acetic acid than the nonenzyme-treated wines. The results indicated that pectase treatment seemed to promote the production of acetic acid. 
TABLE 2: Major volatiles ( $\mu \mathrm{g} / \mathrm{g})$ for extracted and nonextracted wine, with and without pectase treatment.

\begin{tabular}{|c|c|c|c|c|c|}
\hline \multirow{2}{*}{ Group } & \multirow{2}{*}{ Compound } & \multicolumn{2}{|c|}{ Extracted } & \multicolumn{2}{|c|}{ Nonextracted } \\
\hline & & Pectase & Control & Pectase & Control \\
\hline \multirow{12}{*}{ Alcohol } & 1-Propanol & $0.53 \pm 0.04^{\mathrm{a}}$ & $0.48 \pm 0.04^{\mathrm{a}}$ & $0.71 \pm 0.10^{\mathrm{b}}$ & $0.85 \pm 0.12^{\mathrm{b}}$ \\
\hline & Isobutyl alcohol & $38.73 \pm 0.65^{\mathrm{a}}$ & $46.13 \pm 1.06^{\mathrm{b}}$ & $55.21 \pm 2.61^{c}$ & $55.20 \pm 4.68^{c}$ \\
\hline & 1-Butanol & $0.12 \pm 0.01^{\mathrm{a}}$ & $0.10 \pm 0.01^{\mathrm{a}}$ & $0.11 \pm 0.02^{\mathrm{a}}$ & $0.13 \pm 0.02^{\mathrm{a}}$ \\
\hline & Isoamyl alcohol & $153.59 \pm 3.06^{\mathrm{a}}$ & $165.62 \pm 3.20^{\mathrm{b}}$ & $205.86 \pm 5.24^{c}$ & $211.90 \pm 10.28^{\mathrm{C}}$ \\
\hline & 3-Ethoxy-1-propanol & $0.16 \pm 0.01^{\mathrm{a}}$ & $0.13 \pm 0.01^{\mathrm{b}}$ & $0.21 \pm 0.01^{\mathrm{c}}$ & $0.12 \pm 0.03^{\mathrm{ab}}$ \\
\hline & 3-Hexen-1-ol & $0.09 \pm 0.01^{\mathrm{a}}$ & $0.08 \pm 0.00^{\mathrm{a}}$ & $0.31 \pm 0.08^{\mathrm{b}}$ & $0.33 \pm 0.04^{\mathrm{b}}$ \\
\hline & 2,3-Butanediol & $0.07 \pm 0.01^{\mathrm{a}}$ & n.d. ${ }^{b}$ & $0.03 \pm 0.01^{c}$ & $0.03 \pm 0.01^{c}$ \\
\hline & alpha-Terpineol & $0.19 \pm 0.02^{\mathrm{a}}$ & $0.17 \pm 0.01^{\mathrm{a}}$ & $0.26 \pm 0.03^{\mathrm{b}}$ & $0.25 \pm 0.01^{\mathrm{b}}$ \\
\hline & 3-Methylthiopropanol & $1.11 \pm 0.13^{\mathrm{a}}$ & $1.43 \pm 0.02^{\mathrm{b}}$ & $1.39 \pm 0.21^{\mathrm{abc}}$ & $1.57 \pm 0.10^{c}$ \\
\hline & Benzyl alcohol & $0.07 \pm 0.00^{\mathrm{a}}$ & n.d. ${ }^{b}$ & $0.12 \pm 0.03^{c}$ & n.d. ${ }^{\text {b }}$ \\
\hline & Phenylethyl alcohol & $50.95 \pm 4.56^{\mathrm{a}}$ & $52.14 \pm 1.58^{\mathrm{a}}$ & $59.67 \pm 3.36^{\mathrm{b}}$ & $67.23 \pm 2.24^{\mathrm{c}}$ \\
\hline & 3-Ethyl-1-butanol & n.d. ${ }^{\mathrm{a}}$ & n.d. ${ }^{\mathrm{a}}$ & $0.14 \pm 0.02^{\mathrm{b}}$ & $0.11 \pm 0.01^{c}$ \\
\hline Total & & 245.61 & 266.28 & 324.02 & 337.72 \\
\hline \multirow{9}{*}{ Acid } & Acetic acid & $8.22 \pm 0.08^{\mathrm{a}}$ & $4.99 \pm 0.45^{\mathrm{b}}$ & $11.11 \pm 1.83^{\mathrm{c}}$ & $4.47 \pm 0.12^{\mathrm{b}}$ \\
\hline & Isobutyric acid & $1.19 \pm 0.05^{\mathrm{a}}$ & $1.63 \pm 0.12^{\mathrm{b}}$ & $1.66 \pm 0.25^{\mathrm{b}}$ & $2.15 \pm 0.24^{\mathrm{b}}$ \\
\hline & Butanoic acid & $0.15 \pm 0.01^{\mathrm{a}}$ & $0.18 \pm 0.00^{\mathrm{b}}$ & $0.17 \pm 0.03^{\mathrm{ab}}$ & $0.35 \pm 0.05^{\mathrm{c}}$ \\
\hline & 2-Methyl butyric acid & $1.02 \pm 0.05^{\mathrm{a}}$ & $1.14 \pm 0.07^{\mathrm{a}}$ & n.d. ${ }^{b}$ & $1.39 \pm 0.12^{\mathrm{c}}$ \\
\hline & Hexanoic acid & $0.72 \pm 0.05^{\mathrm{a}}$ & $0.66 \pm 0.04^{\mathrm{a}}$ & $0.56 \pm 0.04^{\mathrm{b}}$ & $0.56 \pm 0.04^{\mathrm{b}}$ \\
\hline & Octanoic acid & $1.58 \pm 0.07^{\mathrm{a}}$ & $1.37 \pm 0.10^{\mathrm{b}}$ & $1.09 \pm 0.06^{\mathrm{c}}$ & $0.56 \pm 0.08^{\mathrm{d}}$ \\
\hline & $n$-Decanoic acid & $0.60 \pm 0.04^{\mathrm{a}}$ & $0.51 \pm 0.01^{\mathrm{b}}$ & $0.63 \pm 0.01^{\mathrm{a}}$ & $0.15 \pm 0.04^{\mathrm{c}}$ \\
\hline & 9-Decenoic acid & $0.58 \pm 0.06^{\mathrm{a}}$ & $0.30 \pm 0.03^{\mathrm{b}}$ & $0.15 \pm 0.07^{\mathrm{c}}$ & $0.12 \pm 0.03^{c}$ \\
\hline & n-Hexadecanoic acid & $0.38 \pm 0.06^{\mathrm{a}}$ & $0.52 \pm 0.07^{\mathrm{b}}$ & $0.47 \pm 0.09^{\mathrm{ab}}$ & $0.30 \pm 0.04^{\mathrm{a}}$ \\
\hline Total & & 14.44 & 11.30 & 15.84 & 10.05 \\
\hline \multirow{13}{*}{ Ester } & Isoamyl acetate & $0.06 \pm 0.00^{\mathrm{a}}$ & $0.05 \pm 0.00^{\mathrm{b}}$ & $0.14 \pm 0.01^{\mathrm{c}}$ & $0.09 \pm 0.03^{\mathrm{d}}$ \\
\hline & Ethyl hexanoate & $0.10 \pm 0.02^{\mathrm{a}}$ & $0.10 \pm 0.01^{\mathrm{a}}$ & $0.08 \pm 0.01^{\mathrm{a}}$ & $0.10 \pm 0.02^{\mathrm{a}}$ \\
\hline & Ethyl pyruvate & $0.11 \pm 0.01^{\mathrm{a}}$ & $0.11 \pm 0.02^{\mathrm{a}}$ & $0.11 \pm 0.01^{\mathrm{a}}$ & $0.10 \pm 0.02^{\mathrm{a}}$ \\
\hline & Ethyl lactate & $0.68 \pm 0.04^{\mathrm{a}}$ & $0.69 \pm 0.04^{\mathrm{a}}$ & $1.31 \pm 0.04^{\mathrm{b}}$ & $1.42 \pm 0.21^{\mathrm{b}}$ \\
\hline & Ethyl octanoate & $0.22 \pm 0.02^{\mathrm{a}}$ & $0.17 \pm 0.02^{\mathrm{b}}$ & $0.17 \pm 0.01^{b}$ & $0.08 \pm 0.01^{\mathrm{c}}$ \\
\hline & Ethyl 3-hydroxybutyrate & $0.02 \pm 0.00^{\mathrm{a}}$ & $0.02 \pm 0.00^{\mathrm{a}}$ & $0.02 \pm 0.01^{\mathrm{a}}$ & $0.02 \pm 0.00^{\mathrm{a}}$ \\
\hline & Butyrolactone & $0.21 \pm 0.03^{\mathrm{a}}$ & $0.33 \pm 0.02^{\mathrm{b}}$ & $0.30 \pm 0.07^{\mathrm{ab}}$ & $0.41 \pm 0.08^{\mathrm{b}}$ \\
\hline & Diethyl butanedioate & $0.06 \pm 0.01^{\mathrm{a}}$ & $0.04 \pm 0.00^{\mathrm{b}}$ & $0.07 \pm 0.01^{\mathrm{a}}$ & $0.05 \pm 0.01^{\mathrm{b}}$ \\
\hline & 2-Phenylethyl acetate & $0.11 \pm 0.01^{\mathrm{a}}$ & $0.12 \pm 0.00^{\mathrm{a}}$ & $0.23 \pm 0.04^{\mathrm{b}}$ & $0.13 \pm 0.07^{\mathrm{ab}}$ \\
\hline & Ethyl palmitate & $0.10 \pm 0.01^{\mathrm{a}}$ & $0.21 \pm 0.01^{\mathrm{b}}$ & $0.13 \pm 0.05^{\mathrm{a}}$ & $0.03 \pm 0.00^{c}$ \\
\hline & Ethyl 9-hexadecenoate & $0.05 \pm 0.00^{\mathrm{a}}$ & $0.11 \pm 0.01^{\mathrm{b}}$ & $0.06 \pm 0.02^{\mathrm{a}}$ & $0.02 \pm 0.00^{c}$ \\
\hline & Ethyl octadecanoate & $0.13 \pm 0.01^{\mathrm{a}}$ & $0.18 \pm 0.01^{b}$ & $0.12 \pm 0.05^{\mathrm{a}}$ & $0.03 \pm 0.01^{c}$ \\
\hline & Ethyl oleate & $0.14 \pm 0.04^{\mathrm{a}}$ & $0.50 \pm 0.04^{\mathrm{b}}$ & $0.22 \pm 0.07^{\mathrm{a}}$ & $0.04 \pm 0.02^{c}$ \\
\hline Total & & 1.99 & 2.63 & 2.96 & 2.52 \\
\hline \multirow{2}{*}{ Aldehyde } & Furfural & $1.77 \pm 0.37^{\mathrm{a}}$ & $0.88 \pm 0.13^{\mathrm{b}}$ & $2.31 \pm 0.32^{\mathrm{a}}$ & $0.20 \pm 0.02^{\mathrm{c}}$ \\
\hline & 5-Methyl furfural & $0.02 \pm 0.01^{\mathrm{a}}$ & $0.06 \pm 0.01^{\mathrm{b}}$ & $0.02 \pm 0.00^{\mathrm{a}}$ & $0.01 \pm 0.00^{\mathrm{a}}$ \\
\hline Ketone & Acetoin & $0.58 \pm 0.05^{\mathrm{a}}$ & $0.53 \pm 0.13^{\mathrm{a}}$ & $1.47 \pm 0.31^{\mathrm{b}}$ & $0.70 \pm 0.11^{\mathrm{a}}$ \\
\hline Others & Eugenol & $0.38 \pm 0.02^{\mathrm{a}}$ & $0.17 \pm 0.02^{\mathrm{b}}$ & $0.34 \pm 0.10^{\mathrm{a}}$ & $0.17 \pm 0.01^{\mathrm{b}}$ \\
\hline
\end{tabular}

n.d.: not detected; ${ }^{\mathrm{a}, \mathrm{b}, \mathrm{c}, \mathrm{d}}$ Statistical analysis at $95 \%$ confidence level with same letters indicating no significant difference.

The third most abundant volatile group in the hawthorn wines was the ester group (Table 2). Most of the esters in the hawthorn wines were produced during fermentation. The nonextracted wines had significantly higher concentrations of ethyl lactate and isoamyl acetate than the extracted wines. Furthermore, the enzyme-treated wines had higher concentrations of both ethyl octanoate and isoamyl acetate than the nonenzyme-treated wines, which is consistent with the quantities of octanoic acid and $n$-decanoic acid between the two kinds of wines. The results indicated that the 


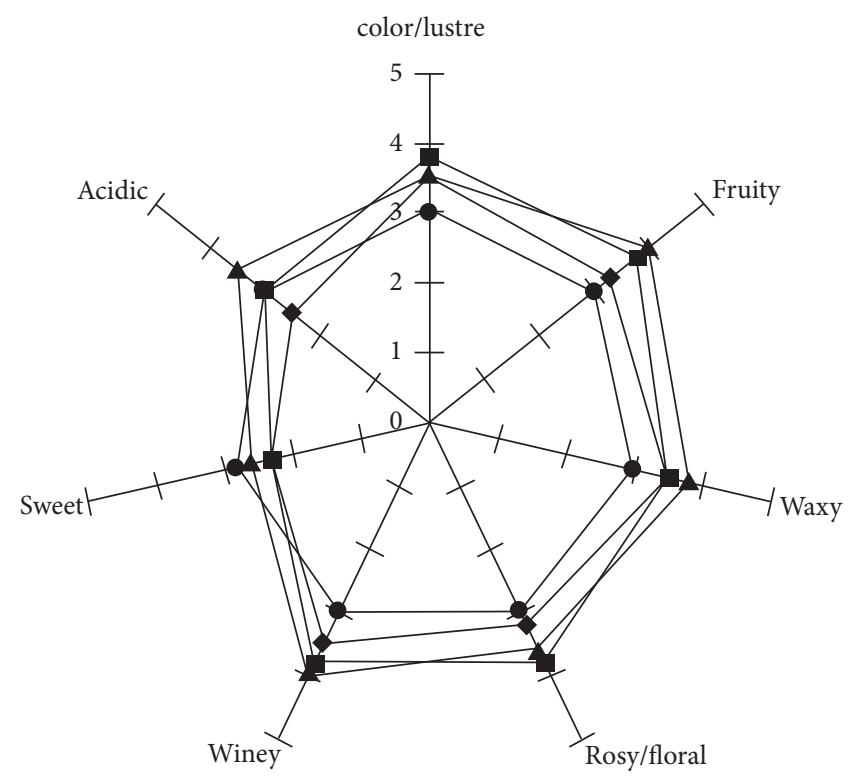

FIGURE 1: Aroma profile of hawthorn wines. Wine from the extracted juice with pectase $(\bullet)$; wine from the extracted juice without pectase

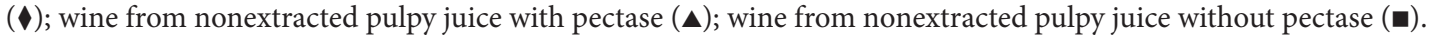

production of fatty acids has the positive correction with the production of ethyl esters, which is in agreement with other report by Li et al. [24].

In Table 2, it could be found that pectase treatment could enhance eugenol, which is main wine flavor. Furthermore, pulp contact can promote production of isoamyl alcohol, phenylethyl alcohol, isoamyl acetate, and ethyl lactate. Hence, the application of pulp contact was effective in enhancing the intensity of hawthorn wine aroma. Furthermore, the addition of pectase to nonextracted juice could accelerate the release of odor-active volatiles such as 3-ethoxy-1-propanol, acetic acid, octanoic acid, n-decanoic acid, isoamyl acetate, ethyl octanoate, ethyl oleate, furfural, acetoin, and eugenol.

3.3. Sensory Characteristics of Hawthorn Wine. The sensory profiles of the hawthorn wines were represented in a spider web plot as shown in Figure 1. The nonextracted wine with pectase treatment showed ruby color and was significantly more aromatic than the rest. These results were in agreement with the results of Table 2. The nonextracted wine with pectase treatment was more acidic than the rest, probably due to higher level of total acid (Table 1).

\subsection{Principal Component Analysis of Volatiles in Hawthorn} Wine. Principal component analysis (PCA) was applied to discriminate the volatile profiles of the hawthorn wines (Figures 2(a) and 2(b)). The first principal component (PC1) accounted for $50.4 \%$ of the total variance in the data set, while the second principal component (PC2) accounted for 31.8\% of the total variance. The PCA biplot separated the thirtyeight different volatile compounds and the four different samples.
The first principal component (PC1) separated the wine from the extracted wine with pectase from other samples based on the higher concentrations of medium-chain fatty acids (octanoic and $n$-hexadecanoic acid) and mediumchain ethyl esters (ethyl octanoate, ethyl palmitate, and ethyl octadecanoate). PC1 also separated the wine from the nonextracted wine without pectase, based on alcohols (butanol and 3-methylthiopropanol), acids (isobutyric and butanoic acid), and esters (ethyl 3-hydroxybutyrate and butyrolactone). PC2 separated the nonextracted wine with enzyme addition and extracted wine without enzyme based on higher concentrations of isoamyl acetate $(0.14 \mu \mathrm{g} / \mathrm{g})$, diethyl butanedioate $(0.07 \mu \mathrm{g} / \mathrm{g}), 2$-phenylethyl acetate $(0.23 \mu \mathrm{g} / \mathrm{g})$, and acetoin $(1.47 \mu \mathrm{g} / \mathrm{g})$ in the former and higher acetic acid in the latter.

3.5. Consumer Acceptability Test of Hawthorn Wine. The results of consumer acceptability test were shown in Figure 3. The wine from nonextracted pulpy juice with pectase (B) showed favorable acceptability compared to the others. It was also found that $26.2 \%$ of the consumers were willing to purchase this product. These results were in agreement with the results of sensory characteristics.

\section{Conclusion}

The chemical and volatile composition of hawthorn wines fermented with $S$. cerevisiae with and without pectase was evaluated. The methanol content was much higher for pectasetreated wine than nonenzyme-treated wines. Although the addition of pectase was in favor of clarification and filtration of wine, the nonextracted wine without pectase treatment was significantly more aromatic than the rest. The results suggested that pulp contact could intensify and diversify the 


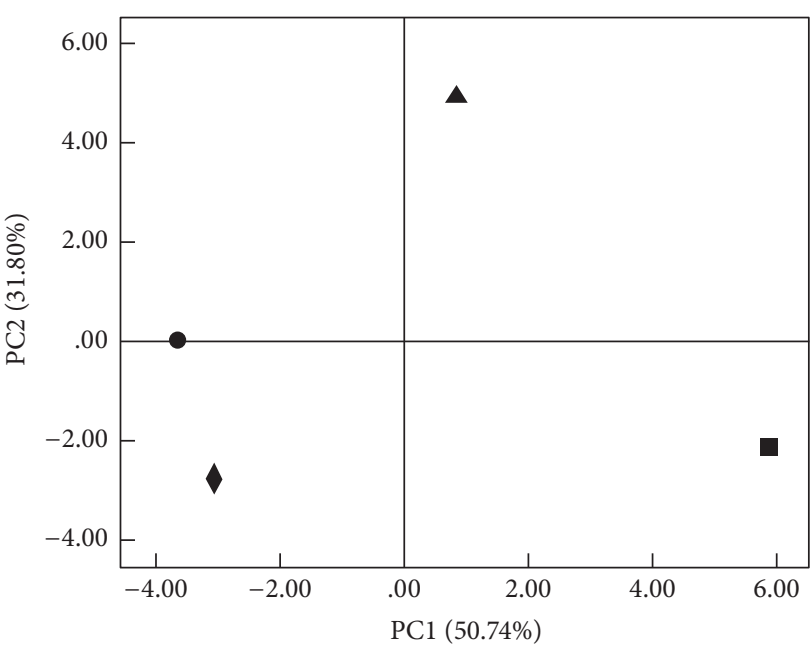

(a)

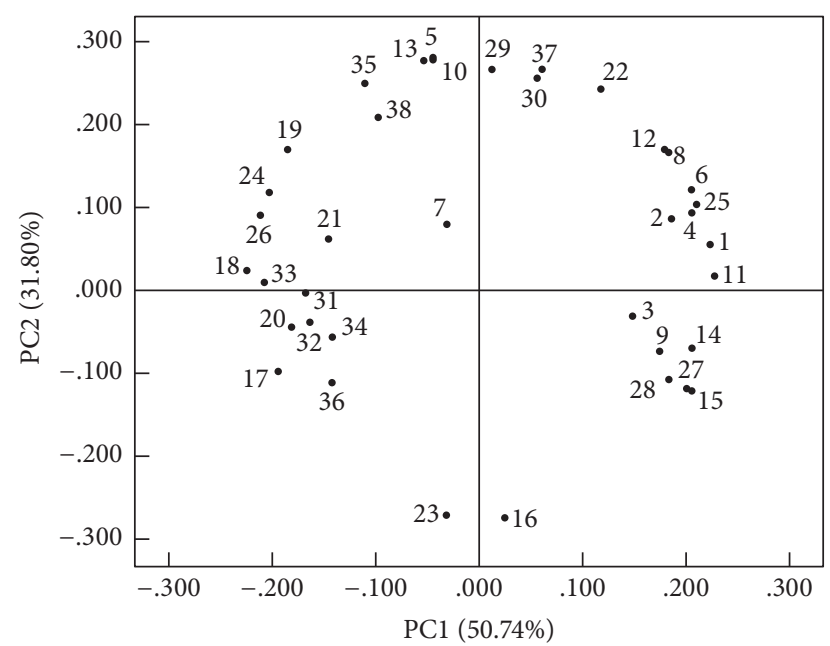

(b)

FIGURE 2: Biplot of principal component analysis of hawthorn wines. (a) Wine from the extracted juice with pectase (๑); wine from the extracted juice without pectase ( $)$; wine from nonextracted pulpy juice with pectase ( $\mathbf{\Delta})$; wine from nonextracted pulpy juice without pectase (匹); (b) aroma compositions: (1) 1-propanol; (2) isobutyl alcohol; (3) 1-butanol; (4) isoamyl alcohol; (5) 3-ethoxy-1-propanol; (6) 3-hexen-1-ol; (7) 2,3-butanediol; (8) alpha-terpineol; (9) 3-methylthiopropanol; (10) benzyl alcohol; (11) phenylethyl alcohol; (12) 3-ethyl-1-butanol; (13) acetic acid; (14) isobutyric acid; (15) butanoic acid; (16) 2-methyl butyric acid; (17) hexanoic acid; (18) octanoic acid; (19) n-decanoic acid; (20) 9-decenoic acid; (21) n-hexadecanoic acid; (22) isoamyl acetate; (23) ethyl hexanoate; (24) ethyl pyruvate; (25) ethyl lactate; (26) ethyl octanoate; (27) ethyl 3-hydroxybutyrate; (28) butyrolactone; (29) diethyl butanedioate; (30) 2-phenylethyl acetate; (31) ethyl palmitate; (32) Ethyl 9-hexadecenoate; (33) ethyl octadecanoate; (34) ethyl oleate; (35) furfural; (36) 5-methyl furfural; (37) acetoin; (38) eugenol.
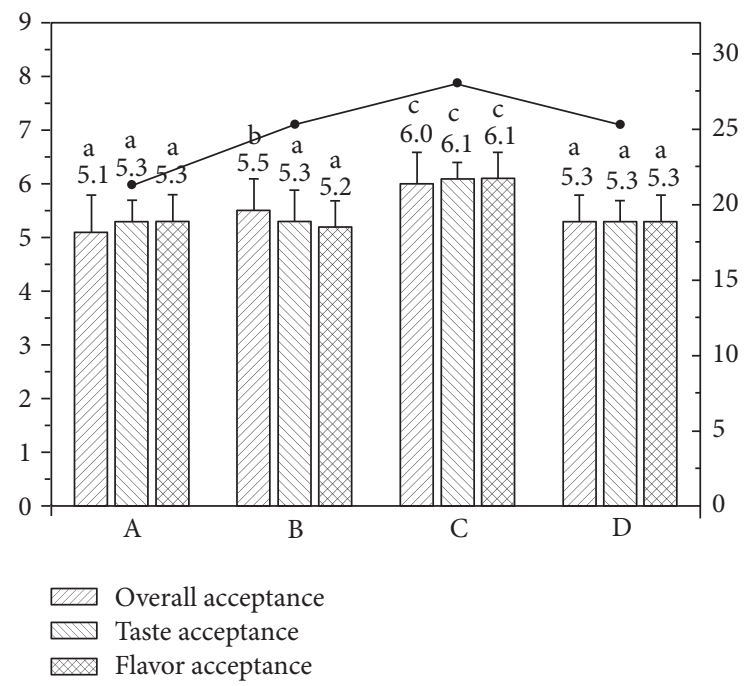

FIGURE 3: Consumer acceptability test of hawthorn wine. Left ordinate represents score of acceptance and right ordinate represents percentage of purchase intention. (A) Wine from the extracted juice with pectase, (B) wine from the extracted juice without pectase, (C) wine from nonextracted pulpy juice with pectase, and (D) wine from nonextracted pulpy juice without pectase.

aroma profile of hawthorn wine, while pectase treatment could be in favor of wine clarity and accelerate the release of methanol. These findings have implications for controlling fruit wine fermentation. Further work on decrease of methanol content is in progress in our laboratory.

\section{Conflicts of Interest}

The authors declare that there are no conflicts of interest regarding the publication of this paper.

\section{Acknowledgments}

This work was supported by the National Science Foundation of China (B060806 and U1604176).

\section{References}

[1] C.-Y. Kwok, C. Li, H.-L. Cheng et al., "Cholesterol lowering and vascular protective effects of ethanolic extract of dried fruit of Crataegus pinnatifida, hawthorn (Shan Zha), in diet-induced hypercholesterolaemic rat model," Journal of Functional Foods, vol. 5, no. 3, pp. 1326-1335, 2013.

[2] T.-P. Li, R.-G. Zhu, Y.-P. Dong, Y.-H. Liu, S.-H. Li, and G. Chen, "Effects of pectin pentaoligosaccharide from hawthorn (Crataegus pinnatifida Bunge. var. Major) on the activity and mRNA levels of enzymes involved in fatty acid oxidation in the liver of mice fed a high-fat diet," Journal of Agricultural and Food Chemistry, vol. 61, no. 31, pp. 7599-7605, 2013.

[3] B. Yang and P. Liu, "Composition and health effects of phenolic compounds in hawthorn (Crataegus spp.) of different origins," Journal of the Science of Food and Agriculture, vol. 92, no. 8, pp. 1578-1590, 2012.

[4] G. He, J. Sui, J. Du, and J. Lin, "Characteristics and antioxidant capacities of five hawthorn wines fermented by different wine yeasts," Journal of the Institute of Brewing, vol. 119, no. 4, pp. 321327, 2013. 
[5] G. Fia, V. Canuti, and I. Rosi, "Evaluation of potential side activities of commercial enzyme preparations used in winemaking," International Journal of Food Science \& Technology, vol. 49, no. 8, pp. 1902-1911, 2014.

[6] B. Liu, X.-Q. Xu, J. Cai, Y.-B. Lan, B.-Q. Zhu, and J. Wang, "The free and enzyme-released volatile compounds of distinctive Vitis amurensis var. Zuoshanyi grapes in China," European Food Research and Technology, vol. 240, no. 5, pp. 985-997, 2015.

[7] K. Ahumada, A. Martínez-Gil, Y. Moreno-Simunovic, A. Illanes, and L. Wilson, "Aroma release in wine using co-immobilized enzyme aggregates," Molecules, vol. 21, no. 11, article 1485, 2016.

[8] R. Apolinar-Valiente, P. Williams, G. Mazerolles et al., "Effect of enzyme additions on the oligosaccharide composition of Monastrell red wines from four different wine-growing origins in Spain," Food Chemistry, vol. 156, pp. 151-159, 2014.

[9] G. González-Neves, G. Favre, D. Piccardo, and G. Gil, "Anthocyanin profile of young red wines of Tannat, Syrah and Merlot made using maceration enzymes and cold soak," International Journal of Food Science \& Technology, vol. 51, no. 1, pp. 260-267, 2016.

[10] W. Zhang, L. Zhang, and C. Xu, "Chemical and volatile composition of jujube wines fermented by Saccharomyces cerevisiae with and without pulp contact and protease treatment," Food Science and Technology, vol. 36, no. 2, pp. 204-209, 2016.

[11] G. L. Robertson, "Pectic enzymes and wine making," Food Technology, vol. 12, pp. 34-35, 1977.

[12] K. Rukmini, M. Korivi, and P. S. Devi, "Biochemical characterization of pectinase in Bacillus pumilus isolated from fruit waste," International Journal of Pharmacology and Pharmaceutical Sciences, vol. 3, no. 4, pp. 25-29, 2016.

[13] A. Luo, X. Liu, Y. Ren et al., "Study on ultra-filtration clarification technique of Kiwi-fruit dry wine," Journal of Chinese Institute of Food Science and Technology, vol. 5, no. 2, pp. 55-59, 2005.

[14] GB/T 15038, "Analytical methods of wine and fruit wine," Tech. Rep., China Standard Press, Beijing, China, 2006.

[15] T. H. Schultz, R. A. Flath, T. R. Mon, S. B. Eggling, and R. Teranishi, "Isolation of volatile components from a model system," Journal of Agricultural and Food Chemistry, vol. 25, no. 3, pp. 446-449, 1977.

[16] J. Cai, B. Liu, P. Ling, and Q. Su, "Analysis of free and bound volatiles by gas chromatography and gas chromatographymass spectrometry in uncased and cased tobaccos," Journal of Chromatography A, vol. 947, no. 2, pp. 267-275, 2002.

[17] Y. Zhao, L. Wang, J. Li, G. Pei, and Q. Liu, "Comparison of volatile compounds in two brandies using HS-SPME coupled with GC-O, GC-MS and sensory evaluation," South African Journal of Enology and Viticulture, vol. 32, no. 1, 2011.

[18] I. A. Baxter, K. Easton, K. Schneebeli, and F. B. Whitfield, "High pressure processing of Australian navel orange juices: sensory analysis and volatile flavor profiling," Innovative Food Science and Emerging Technologies, vol. 6, no. 4, pp. 372-387, 2005.

[19] B. Cheirsilp and K. Umsakul, "Processing of banana-based wine product using pectinase and $\alpha$-amylase," Journal of Food Process Engineering, vol. 31, no. 1, pp. 78-90, 2008.

[20] M. Gerogiannaki-Christopoulou, "Evaluation of methanol concentration in Hellenic traditional alcoholic beverages after grape pomace fermentation at different conditions," Journal of Food Technology, vol. 6, pp. 196-202, 2008.

[21] NY/T 274, "Green food wine," Tech. Rep., Ministry of Agriculture of the People's Republic of China, Beijing, China, 2014.
[22] J. R. Dickinson, M. M. Lanterman, D. J. Danner et al., "A ${ }^{13} \mathrm{C}$ nuclear magnetic resonance investigation of the metabolism of leucine to isoamyl alcohol in Saccharomyces cerevisiae," The Journal of Biological Chemistry, vol. 272, no. 43, pp. 2687126878, 1997.

[23] S.-J. Bell and P. A. Henschke, "Implications of nitrogen nutrition for grapes, fermentation and wine," Australian Journal of Grape and Wine Research, vol. 11, no. 3, pp. 242-295, 2005.

[24] X. Li, S. L. Lim, B. Yu, P. Curran, and S.-Q. Liu, "Mango wine aroma enhancement by pulp contact and $\beta$-glucosidase," International Journal of Food Science \& Technology, vol. 48, no. 11, pp. 2258-2266, 2013. 

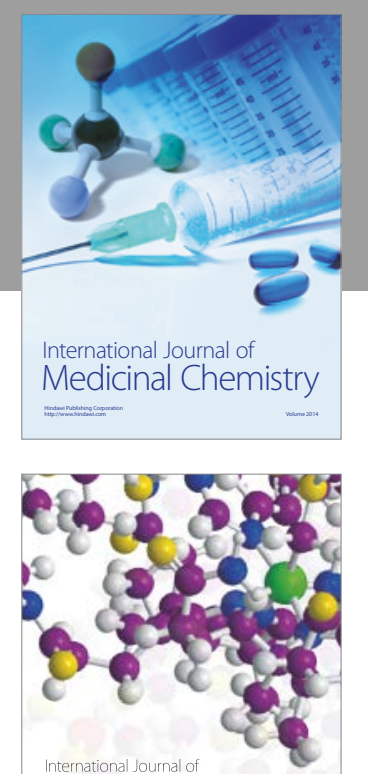

Carbohydrate Chemistry

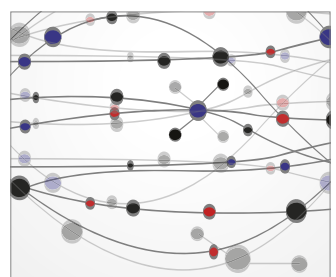

The Scientific World Journal
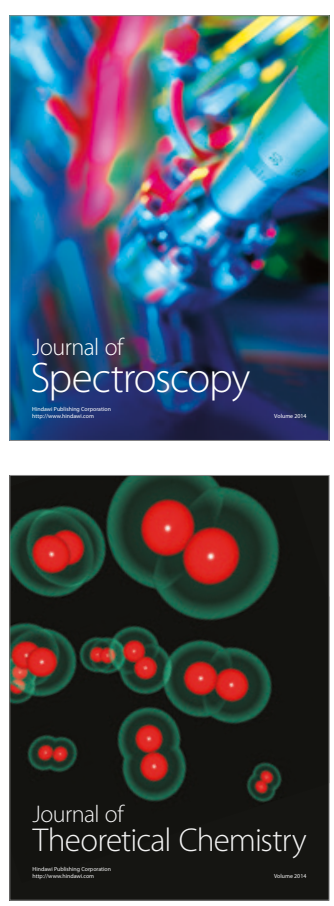
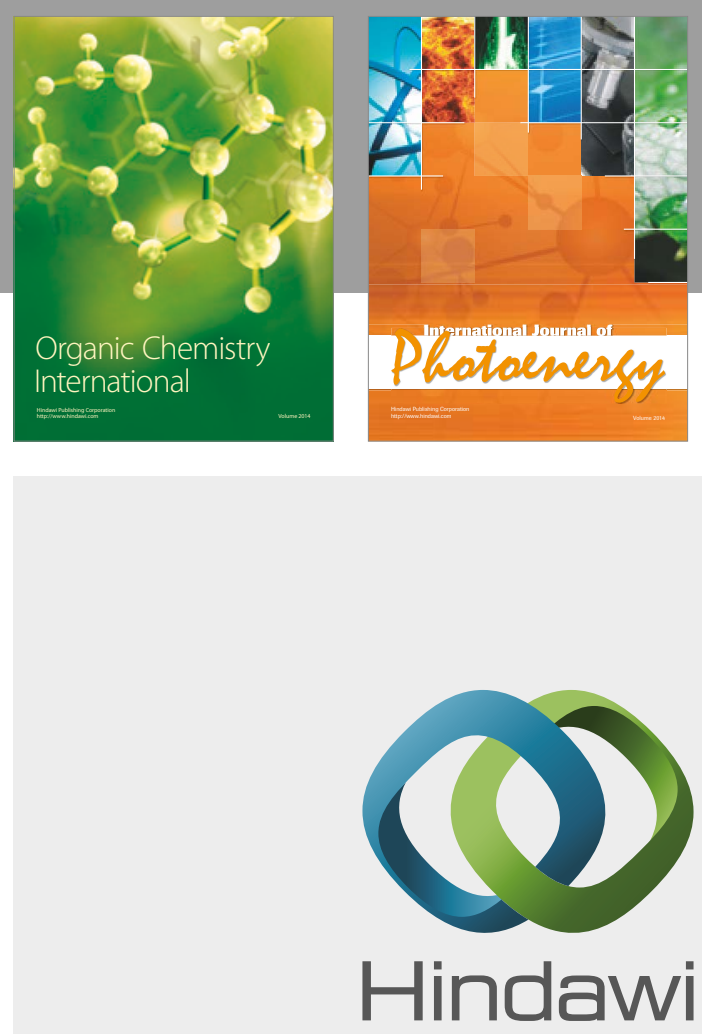

Submit your manuscripts at

https://www.hindawi.com

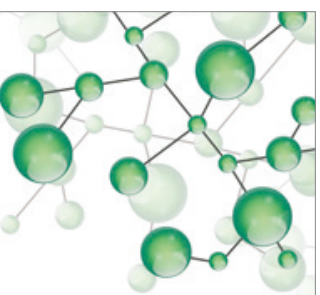

International Journal of

Inorganic Chemistry

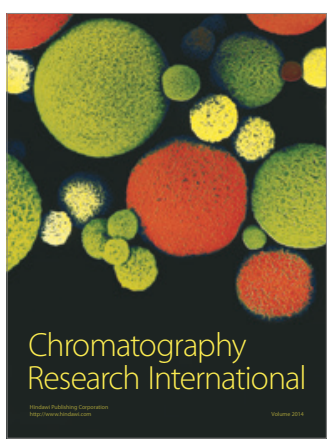

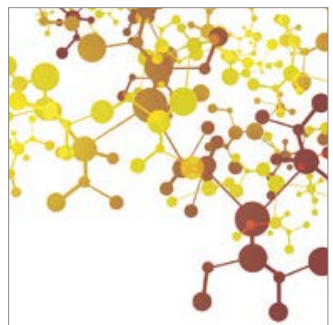

Applied Chemistry
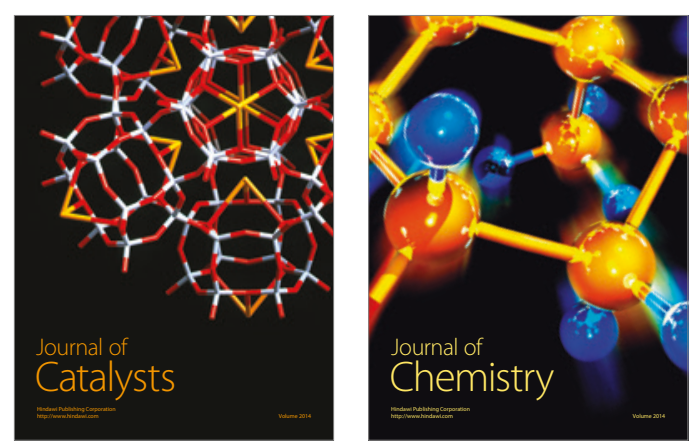
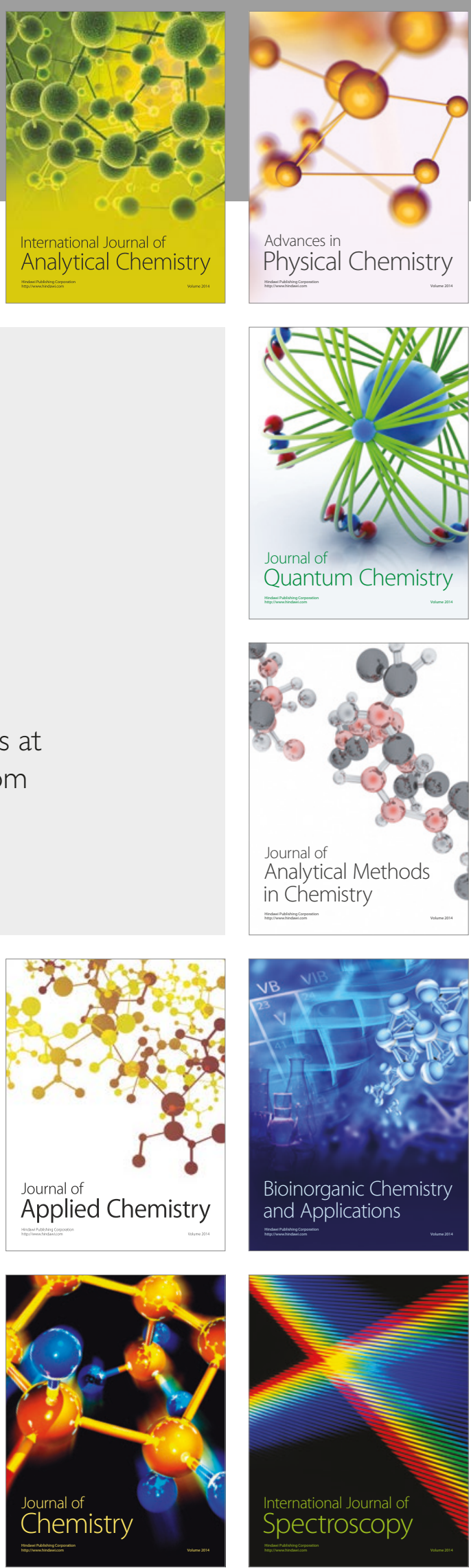